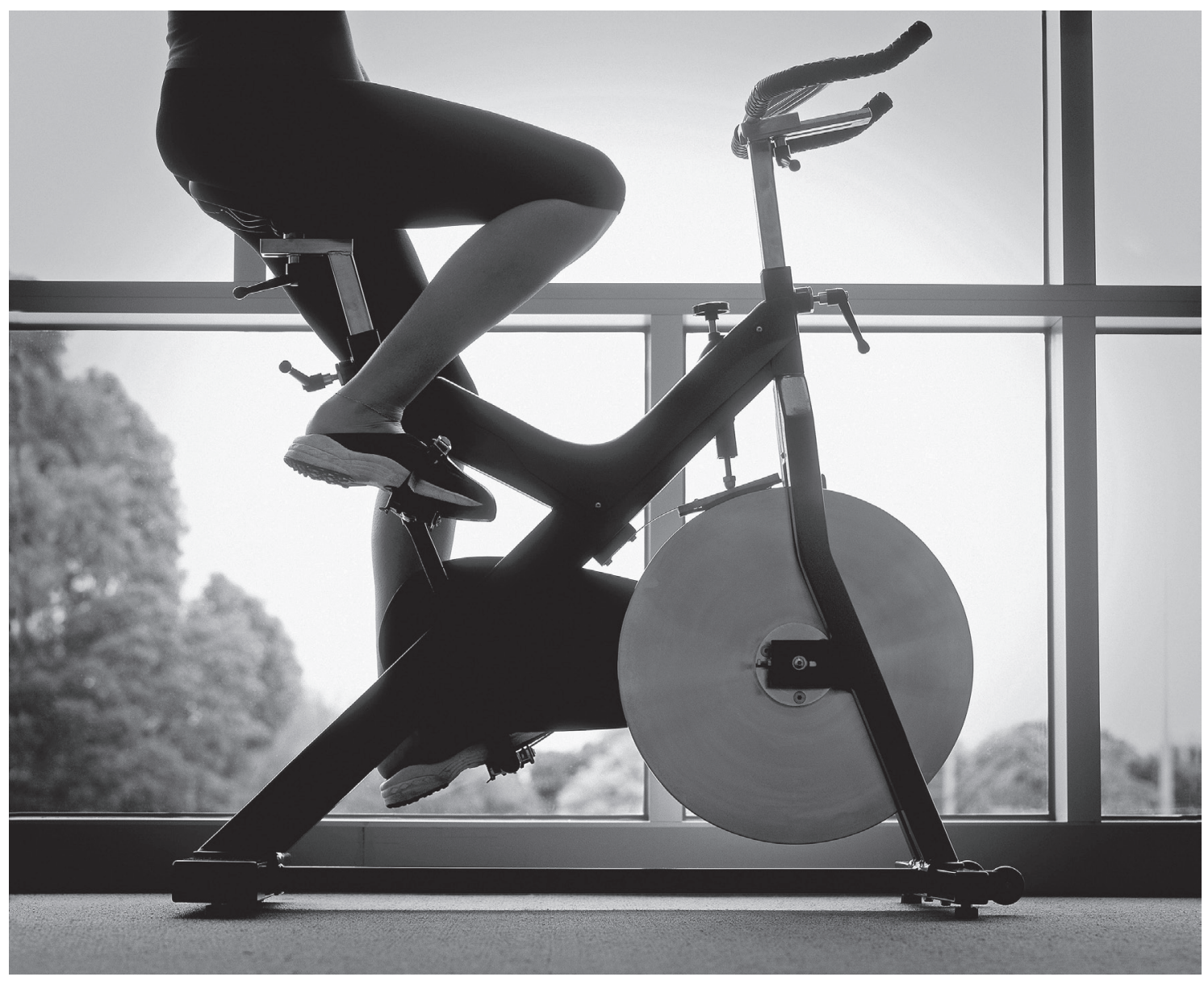

Kondicyklen og den senere spinningcykel er for mange idrætssociologer et udtryk for en fattig, ensformig idrætskultur. Alligevel sætter flere og flere danskere sig op på dem og træder løs i pedalerne - og flertallet af dem er tilmed godt tilfredse med deres idræt (Dombrovskaya Anastassiya fot., Dreamstime.com).

\title{
Fitnesskultur mellem lyst og pligt
}




\section{LYSTEN SOM LIVETS KILDE}

Forholdet mellem lyst og pligt er et tema, der er blevet belyst uendeligt mange gange i kunstens historie, fordi et af menneskelivets store dilemmaer består $\mathrm{i}$ at vælge side og tage stilling: På den ene side kan der føres et fundamentalt usikkert liv præget af spænding, lyst, sanselighed, begær og erotik. På den anden side kan et liv med borgerlighedens formalistiske tryghed vælges, hvor stærke sociale normer, traditioner, roller og rutiner samt en snigende kedsomhed hersker som kærlighedens trofaste følgesvende. Tanker om det erotiske, om forførelse, om følelsesmæssig splittelse og om ægteskabet har i dansk kontekst især været Søren Kierkegaards speciale, hvor mesterværket 'Enten Eller' står som en eksemplarisk skildring af kampene mellem æstetikerens søgen efter lystopfyldelse og pligtens begrænsende fornuft. Kierkegaards pointe er klar: Såfremt man ikke holder de rene varianter af lyst eller pligt på afstand, så ender det i menneskeligt forfald.

Lad os fortsætte tankeeksperimentet: Tænk hvis livet blev levet som en destilleret udgave af lyst.

Hvad ville det da føre til? Ulykke og ufrihed!

Vi kender godt typen, som oftest er af hankøn. Rastløst drives han rundt i manegen af en nydelsestvang, der fører til kortsigtede beslutninger og en ukontrolleret søgen mod tilfredsstillelse. Et liv ført efter lysten resulterer i overforbrug og snæversynet egoisme, hvor søgen og jagt hurtigt bliver vigtigere end byttet. Paradoksalt nok indebærer livsførelsen stor risiko for at havne $\mathrm{i}$ et liv fyldt med ufrihed, selv om hensigten i udgangspunktet var præcis det modsatte: At blive fri. Fri fra menigmands normer om 'korrekt opførsel' og fri fra formynderiske indgreb i den personlige frihed. Frihed til at følge sine indre lyster uden hensyntagen til smålige, snærende bånd. Men netop fordi han ikke evner at tøjle sine lyster og sine behov, ender han med at blive slave af dem. Som rockstjernen Bryan Ferry synger med sin karakteristiske dirrende, skrøbelige stemme i hittet fra 1985: "We're the restless hearted. Not the chained and bound. But I'm a slave to love. And I can't escape; I'm a slave to love« (Ferry, 1985).

\section{PLIGTEN SOM LIVETS VILKÅR}

Tænk hvis livet omvendt blev levet som en destilleret udgave at pligt.

Hvad ville det føre til? Ulykke og ufrihed!

Vi kender også pligtens person, som ofte bindes op på samvittighedens, moralens, religionens bud. Pligten personificeres af autoritære skikkelser, hvis ekspertise består i forkyndelse af fastholdelsen af den disciplinerede sjæl og krop. Pligtens sprog er fyldt med den befalende bydeform, hvor levevisen er selvdisciplineringens kunst. Tankens selvjustits løber som en rød tråd gennem livet, hvor der er bundet faste knudepunkter op på den dårlige samvittighed, skammen og skyldfølelsen. Disciplinen holdes ved lige via streng insisteren på at leve efter bestemte forskrifter, som ofte er nedfældet i sammensatte ledetråde, religiøse overbevisninger eller politiske ideologier, der giver anvisninger til dydens smalle sti. Den praktiserede disciplinerede livsførelse forsøges samtidig legitimeret af autoriteter via løftet om social anerkendelse i livet samt åndelig og kropslig frelse, når døden i bogstaveligste forstand indtræffer. Resultatet kan for den udenforstående opfattes som et liv fyldt med umyndiggørelse, fordi livet rummer klare elementer af kropslig og åndelig selvpinsel og skam. Således er kroppen som udgangspunktet i den protestantiske læsning af biblen syndig og skal disciplineres. Dette har den britiske elektro-popduo Pet Shop Boys sunget om 
med hittet It's a Sin, hvor skamfølelsen over at være homoseksuel resulterer i det hårdtpumpede omkvæd, der lyder: "Everything I've ever done, Everything I ever do, Every place I've ever been, Everywhere I'm going to - It's a sin!« (Tennant, 1987).

\section{ARBEJDETS PLIGT OG FRITIDENS LYST?}

Selv om kunstens udtryksformer til alle tider har kredset om problemstillingerne, er de fleste levede liv i den vestlige verden vel sagtens sjældent direkte i berøring med de koncentrerede udgaver af pligt og lyst. Yderpunkterne mellem de rendyrkede ekstremer er holdt på behagelig afstand af civilsamfundets eller velfærdsstatens sikkerhedsnet og et alment menneskeligt behov for at leve et pragmatisk og trygt hverdagsliv.

Alligevel forbindes pligtbegrebet rent historisk ofte med det hårde fysiske arbejde, som mennesket tvinges til at udføre af nød for at overleve. I industrisamfundets epoke kastede masserne $\mathrm{i}$ den arbejdsdygtige alder sig ud i samlebåndsarbejdets dyder under forudsætning af, at balancen mellem at "gøre sin pligt og kræve sin ret"1 blev opretholdt, hvilket er et belæg for, at arbejdslogikken ligger tættere på pligtens end lystens logik. Industriarbejderes organisering i fagforeninger understreger også dette faktum. Arbejdsbegrebet og arbejdets motiv lå dengang uden for arbejdet selv, og lønnen gav mennesket mulighed for at overleve og udvikle sig i den fritid, der var til overs efter arbejdet. Lønnen var det, der fik industriarbejderen til at gentage arbejdets påtvungne proces igen og igen. Arbejdet var midlet og fritiden målet.

\section{PLIGTEN OG LYSTEN II IDRAETTENS VERDEN}

Når man fra dette lyst-pligt-perspektiv kigger nærmere på idrætten, synes udviklingen i de seneste 40 år blandt voksne danskeres idrætsva-

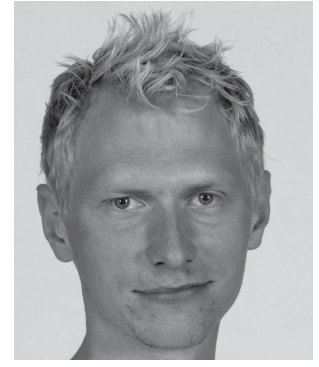

AF

KASPER LUND

KIRKEGAARD

ner at vise, at ydre pligtmotiver og begrundelser for idrætsaktivitet spiller en stadigt større rolle for et stigende antal idrætsaktive. Dette ses tydeligst i væksten inden for motionsidrætter, der til stadighed fylder mere, når danskernes idrætsvaner måles (Pilgaard, 2009). Sportens traditioner om dygtiggørelse, specialisering og konkurrenceorientering er tilsyneladende under pres, da flere og flere idrætsaktive foretrækker at dyrke varianter af motionsidræt, som i høj grad er båret af et fokus på idrættens effektfulde nytte. Idrætten instrumentaliseres således som et middel til at fremme konkrete, ofte individuelle, kropslige målsætninger frem for at være et mål i sig selv. Men udviklingen fra traditionelle sportsligt dominerede idrætsformer, der ofte byggede på fritidens rum og legende spil og derved ikke opererede med en skarp sondring mellem mål og midler, blevet suppleret med andre idrætsaktiviteter, der ofte finder sted under andre organisationsformer end idrætsforeningen og ofte dyrkes med andre motiver og begrundelser. Denne ændring kan karakteriseres som overgangen fra industrisamfundets foreningsliv og sportens logik til et konkurrencesamfund med fleksible organisationsformer og individuelle sundhedsorienterede og kropsæstetiske idrætsprojekter.

Udviklingen, som peger mod en pligtens motionskultur, er ofte ikke velset fra idrætsforsknin- 
gens side. En særlig tradition inden for idrætssociologien, der har rødder i en stærkt kulturskeptisk tradition med Jean Baudrillards fremragende, men stærkt normative udgivelse Amerika (Baudrillard, 1987). Både avisers faste kulturkritikere og centralt placerede universitetsansatte sætter ind som foreningsidrættens frontkæmpere og kritiserer med en holdningsbaseret forskning, der tager klare forbehold over for motions- og fitnesskulturens monotone bevægelser - dog uden synderlig empirisk interesse for fænomenet. Idrætten har simpelt hen svært ved at blive accepteret og anerkendt, når den har fokus på træningseffekten, har sundhed eller udseendet i centrum og et klart elementet af kommerciel organisering. Koblingen af disse fremmede faktorer virker stærkt provokerende, selv om foreningsidrættens manglende evner til at reagere på nye idrætsmønstre er en af de mest åbenlyse årsager til de private idrætsudbyderes kommercielle succes. Foreningsidrættens trygge socialitet synes truet af den amerikanske idrætskulturs MacDonaldisering, hvor frygten for at ende som ensomme navlepillende narcissister overskygger alle nuancer: "Hvad sker der, når vi hellere vil dyrke os selv i neonbelysningens skær inden døre i fitnesskulturens spejlsale i stedet for at dyrke hinandens samvær (...)?« lyder spørgsmålet retorisk (Thing, 2010).

Der har i tidens løb været en lang række forskellige bud på, hvorledes man kan forstå og adskille de forskellige motiver til idræt, som hen- holdsvis motionskulturen og en mere traditionel idrætskultur repræsenterer. I fremstillingerne fornemmes ofte foragtende undertoner over for motionsidrættens 'fordummende' praksisformer. Enten er motionskulturens fremmarch resultat af forfejlede eller fraværende kulturpolitiske prioriteringer, hvilket var en klar kulturradikal strømning, eller også er det udtryk for en kropslig analfabetisme, hvor den underuddannede krop ikke evner at tage del i idrættens lege og spillets mere kultiverede, nuancerede og dannende udtryksform. Enkelte af de motionskritiske fremstillinger er ligefrem skrevet på en rus af afsky, hvor motionistens tomme øjne, det forvredne ansigt og de stereotype, gentagne kropsbevægelser fremhæves som karikaturen på en idrætskultur, hvor pligtlogikkens monotone gentagelse har fået total dominans over fritidens gøremål: »Er alle mennesker ved alle de apparater i træningslokalet i gang med at bøde for det, de har gjort mod deres kroppe? Har de pålagt sig selv en straf?« (Dekkers, 2008, p. 281). Forestillingerne om, at fitnessfolket selv frivilligt har valgt den disciplinerende idrætskultur synes fjernere end forklaringen om, at de er blevet lokket, snydt eller truet til at bedrive det hårde fysiske arbejde af onde kapitalister, hvis primære markedsføringstrick er at få folkemasserne til at skamme sig over deres egne ulykkelige og utilstrækkelige kroppe.

En af de mere muntre og politiske potente udlægninger udstillede forskellene mellem de lyst-

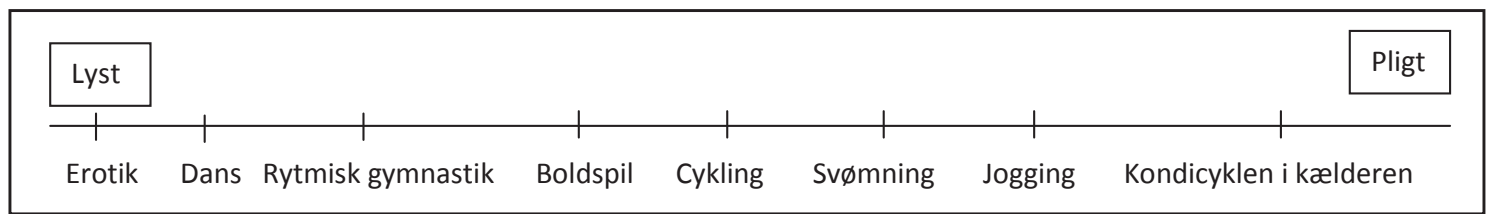

Figur 1. Kilde: Bøje 1989, s. 940. 
baserede og pligtorienterede idrætsaktiviteter som lystens og pligtens modsætninger (se figur 1). I kategoriseringen af idrættens praktiske aktiviteter blev ovenstående lystskala opfundet, hvor en række idrætsaktiviteter blev fordelt på et kontinuum mellem lyst og pligt.

Denne bevidst subjektive provokerende fremstilling var samtidig ensbetydende med en kvalitativ rangering af idrættens kulturer, hvor motionskulturens praktiske fokus ligger under for en (kultur)radikal kritik, mens dansen og den rytmiske gymnastik bliver iscenesat som det interessante, der havde direkte forbindelse til lystens og erotikkens flammer. Figuren beskæftiger sig samtidig med forholdet mellem den praktiske motionsidræt, der reducerer idrætten til et middel, og den iscenesatte og ofte romantiserede idræt, med elementer af (sam)spil, leg, holdfornemmelse og spontanitet og er essentiel for forståelsen af idrættens kvaliteter. Set i dette lys er en funktionel, rationel og resultatorienteret motionsidræt motiveret af ydre omstændigheder ikke en lige så god og fin idræt som den, der legitimeres med driften og lystens idrætslege. Forholdet mellem legens proces og arbejdets pligt er også forsøgt opstillet på ligningsform, hvor det hedder, at "hvis processen er vigtigere end resultatet, leger man. Hvis resultatet er vigtigere end processen, arbejder man« (Møller, 2001, p. 146).

\section{FITNESSKUNDERS TRAENINGSMOTIVER}

I perspektivet af ovenstående kritiske beskrivelser af motionskulturens praksisformer trænger der sig en række spørgsmål på: Hvorfor har de kritiske røster ikke forsøgt at kvalificere deres kritik ved at teste deres hypoteser? Er det virkeligt korrekt, at motionsløbere først og fremmest motiveres af skyldfølelsen og føler sig tvunget ud på gaderne, fordi de er »... skræmt af Hjerte-

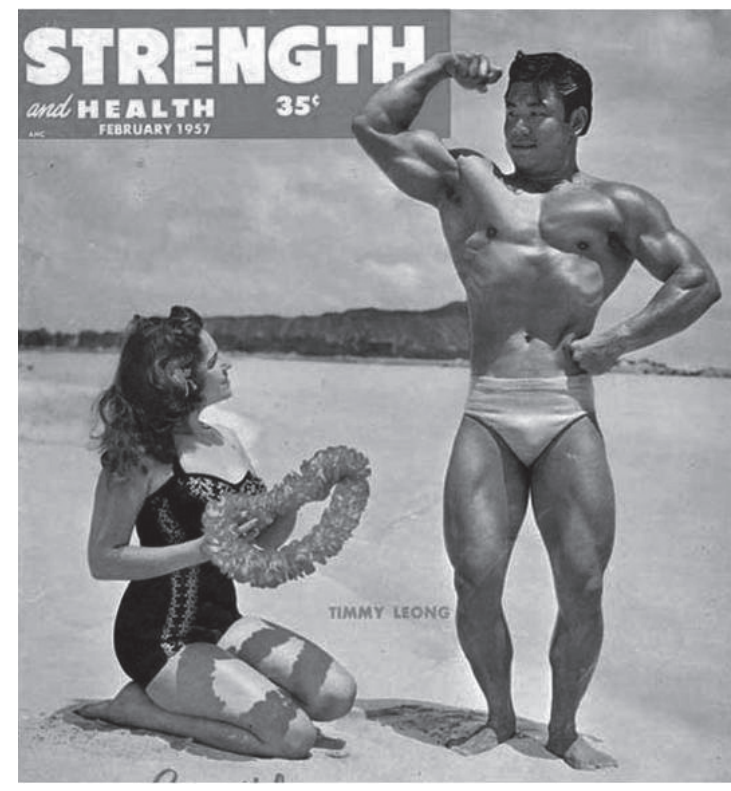

Den passive smukke kvinde og den aktive stærke mand. Kvinden kårer sin udkårne med en blomsterkrans. Lykken og heldet tilsmiler den veltrænede krop. Forside på magasinet Strength and Health fra 1957.

foreningen og behjertede lægers vidnesbyrd om motionens betydning for bekæmpelse af civilisationssygdomme?« (Bøje, 1989, p. 939). Og hvordan kan man på den ene side påstå, at sundhedskampagnerne slår fejl og ikke har nogen gavnlige effekter på danskernes livsførelse (Bøje, 1997, p. 1331), når der på den anden side peges på, at det netop er Hjerteforeningens skræmmekampagner, der får staklerne til at løbe for livet?

Kan skræmmekampagnerne og motionsidrættens discipliner forklare væksten i motionskulturens deltagerantal? Og hvorfor er det netop de ressourcestærke mennesker, der med stærk kulturel kapital i bagagen synes så optagede af at dyrke det pligtbetonede fysiske motionsar- 
bejde - tilmed i den fritid, hvor de ifølge lystlogikken burde ligge henslængt på divanen og praktisere erotikkens kunst eller danse en lidenskabelig tango med naboens datter?

Forklaringerne trænger sig på - og de nemme forklaringer er, at de mange motionister i motionskulturens privilegerede arena, fitnesscentrene, tilsyneladende slet ikke deler opfattelsen af, at deres hårde fysiske træningsarbejde er domineret af pligtens og arbejdets logikker.

Dansk idrætsforskning har kun i beskedent omfang beskæftiget sig med kvantitative undersøgelser af danskernes begrundelser for og motiver til at dyrke idræt. Undersøgelser af denne art har oftest haft kvalitativ karakter. $\mathrm{Nu}$ er der dog offentliggjort et stort kvantitativt empirisk studie af 4.747 aktive fitnesskunders selvvurderede træningsmotiver, hvilket kan medvirke til en ny og mere nuanceret indsigt i motionskulturens selvlegitimering (Kirkegaard, 2009). ${ }^{2}$

Et af de centrale temaer i undersøgelsen fokuserer på, hvordan de aktive fitnesskunder forholder sig til deres træning, og hvilke motiver de selv mener præger deres træningsforhold. Opleves træningen som motiverende eller umotiverende? Er den drevet af lyst eller pligt? Og synes de fitnessaktive, at træningen er sjov eller kedelig? Disse spørgsmål kan således fungere

Figur 2. $(\mathrm{n}=4846)$. Sp.:Hvad har været den vigtigste årsag til din indmeldelse i fitnesscenteret? Kun ét svar er muligt.

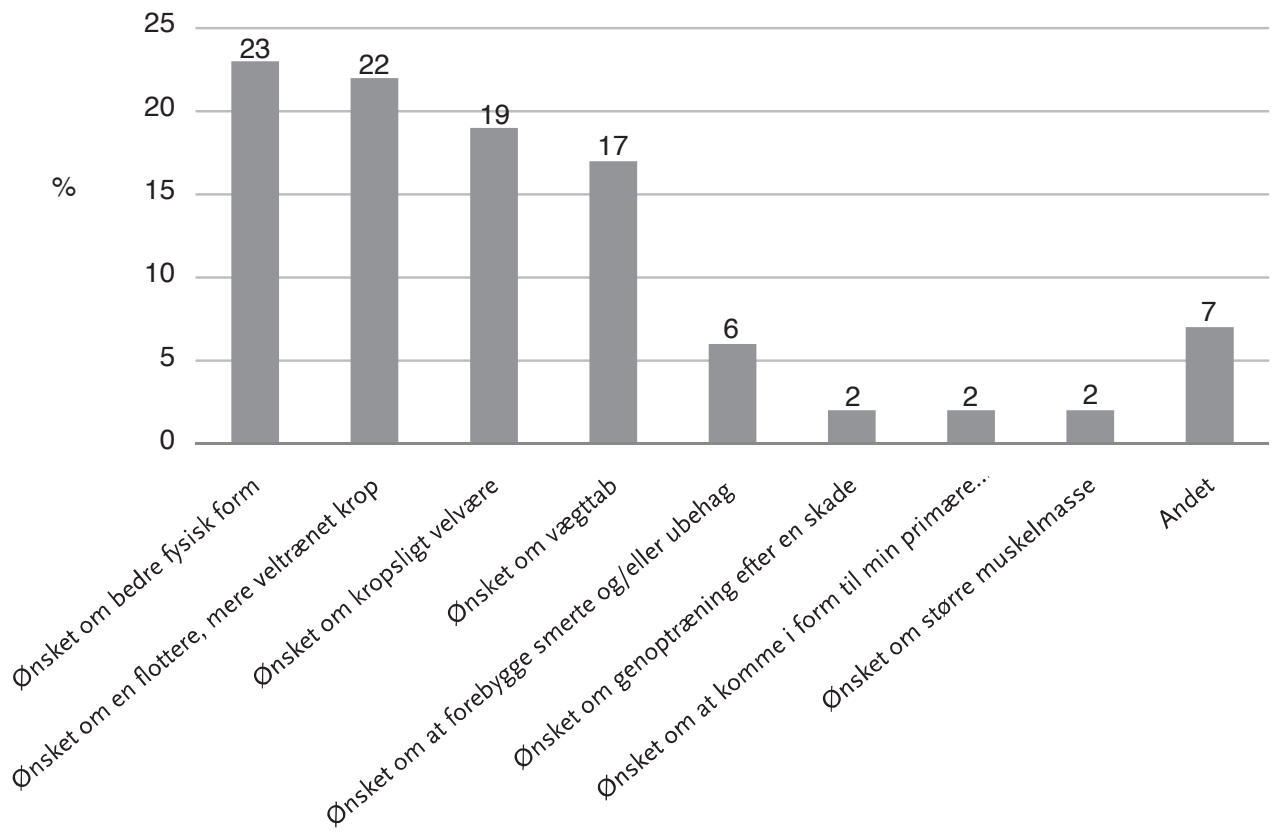


som en empirisk test af de kritiske idrætssociologiske fremstillinger.

Kritikere vil straks hævde, at man da ikke kan kende sine egne indre motiver og drifter, hvorfor man heller ikke kan besvare spørgsmål som disse. Da konsekvensen af et standpunkt som dette læner sig kraftigt op af begrebet 'falsk bevidsthed', er der grund til at give empirien en chance. Det betyder ikke, at empirien giver udtryk for den virkelige verdens sande sammenhænge. Empiriens rolle skal i denne artikels sammenhæng ses som en test af de gængse idrætssociologiske kritiske fremstillinger af den pligtdominerede motions- og fitnesskultur. Både med henblik på at nuancere debatten og med henblik på at beskæftige sig mere empirisk med fitnesskulturen end de kritiske røster tilsyneladende har følt sig for fine til.

\section{FITNESSKUNDERS TRAENINGSMOTIVER}

Når man ser nærmere på fitnesskunders egne svar på spørgsmål om den vigtigste årsag (motiv og begrundelse) til deres indmeldelse i fitnesscentre, fordeler de sig primært over to temaer, henholdsvis sundhed og udseende. Ønsket om en 'bedre fysisk form' og 'ønsket om kropsligt velvære' samler som de to store sundhedskategorier 42 pct. og udgør den hyppigste årsag til medlemskab af et fitnesscenter. De æstetisk dominerede træningsmotiver og -begrundelser som 'ønsket om en flottere og mere veltrænet krop' samt ‘ønsket om vægttab’ samler 39 pct. af svarene.

Samtidig angiver kun 2 pct., at den vigtigste årsag til indmeldelse var ' $ø$ nsket om at få større muskelmasse', hvilket vidner om den markante udvikling, som den kommercielle fitnessbranche har været igennem i de seneste 30 år, hvor man har erstattet de olieindsmurte muskuløse kroppe og klassiske bodybuilderdyder med nutidens træningsformer, der appellerer til langt mindre radikale, og dermed også mere salgbare, kropsidealer. Nutidens fitnesskunder er således ikke udelukkende kropsfokuserede, da tabellen i en krydsning med alderskategorier viser, at de æstetiske træningsmotiver kun dominerer blandt de helt unge fitnesskunder under 30 år. For ældre kunder over 30 år er det i højere grad de sundhedsmæssige aspekter, som er centrum for træningsindsatsen. ${ }^{3}$

Det er således sandt, at nytten (sundheden og udseendet) fylder den idrætslige praksis ud og derfor rummer forklaringen på selve motionsidrættens kvaliteter. Men tilsyneladende synes fitnesskunderne også, i modstrid med kritikken, at deres træning er præget af lyst frem for pligt. I nedenstående figur (se figur 3) ses det, at 68 pct. er 'helt enig« eller »noget enig« med udsagnet om, at "fitnesstræningen er præget af lyst «. Kun 18 pct. abonnerer på det modsatte udsagn "fitnesstræningen er præget af pligt «.

I en krydsning mellem ovenstående svarfordeling og træningsformens organisering, dvs. om man træner individuelt eller på hold, kan det ses, at fitnesskunder, der træner »udelukkende på hold (eksempelvis aerobic eller spinning)«, $\mathrm{i}$ signifikant højere grad end andre fitnesskunder finder, at fitnesstræningen er præget af lyst frem for pligt. Det tyder på, at selve holdorganiseringen rummer kvaliteter, som kan dokumenteres statistisk. Forklaringen kan være, at holdorganiseringen giver rum for dialog med både instruktører og andre fitnesskunder, der deltager. Dette vil sandsynligvis give træningen en meningsgivende ramme, som blandt andet afspejler sig i tilfredshed og lystfølelse. ${ }^{4}$

I nedenstående svarfordeling ser vi tilsvarende, at hele 70 pct. af fitnesskunderne endvidere synes, at fitnesstræning i sig selv er sjov og motiverende. Kun i alt 15 pct. af fitnesskunderne 
Figur 3. $(n=4753)$.

Sp.: Sæt kryds ud for det udsagn, du er mest enig i.

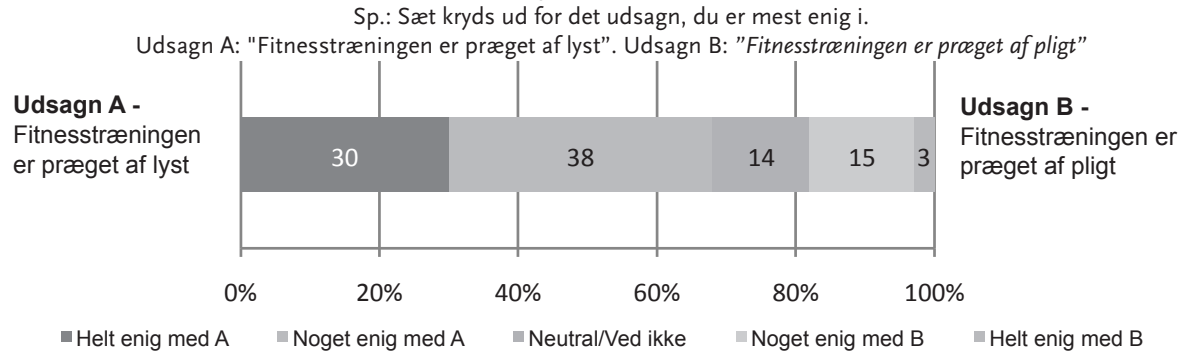

svarer, at de er enige i udsagnet om, at "fitnesstræningen ikke i sig selv er sjov og motiverende«.

Samtidig kan man med en krydsning af alderskategorier se, at de to ældste alderskategorier ('40-49 år' samt '50+') i signifikant højere grad end andre giver udtryk for, at fitnesstræningen er sjov og motiverende i sig selv. Hos begge køn på tværs af alle alderskategorier er der en markant overvægt, der synes, at fitnesstræningen i sig selv er sjov og motiverende.

Da man ikke tidligere har lignende målinger af idrætsaktives træningsmotiver sat over for hinanden som modstridende udsagn, er det vanskeligt at vide, om de empiriske resultater base- ret på aktive fitnesskunder, er overraskende. Men det bør i det mindste stå klart, at den skitserede kritiske idrætssociologiske debat om pligtens dominans bør nuanceres. Det er næppe rene tilfældigheder, der resulterer $i$, at fitnesskunder svarer, som de gør, for der er samstemmende meningsgivende signifikante sammenhænge mellem svarene på tværs af både træningens organisering, alderskategorier og køn (Kirkegaard, 2009).

\section{SOCIOLOGISKE PERSPEKTIVER PÅ LYST, PLIGT OG SUNDHED}

Siden motionsidrættens opblomstring i 1970'erne har motionslogikken suppleret den traditionelle

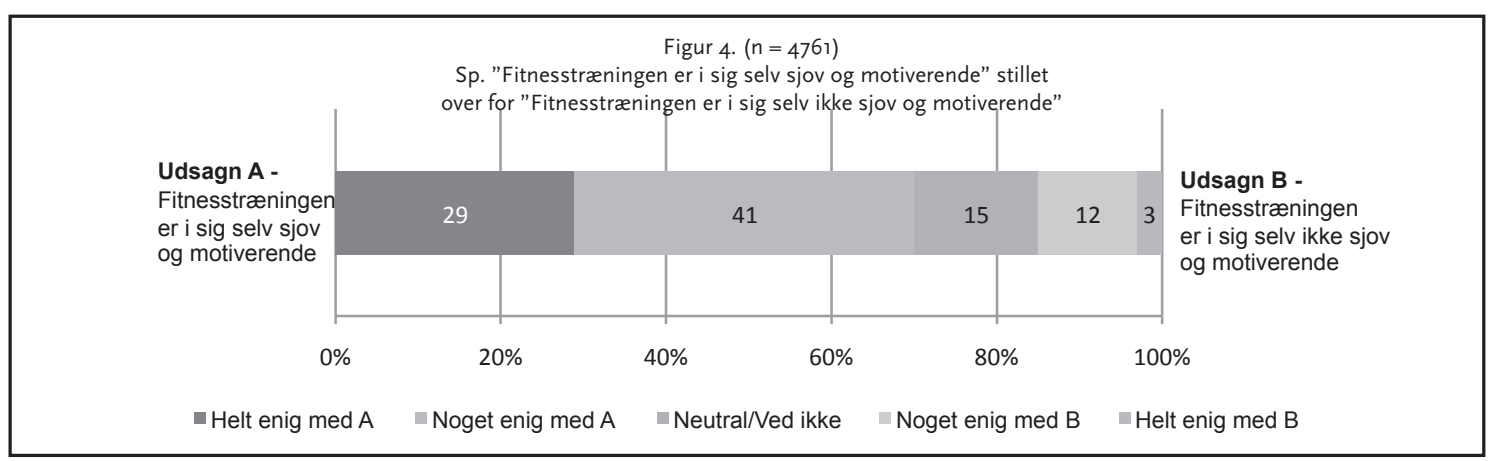


idræt. Udviklingen har potentielt store idrætspolitiske konsekvenser, for store dele af foreningsidrætten ser passivt til, mens idrætsdeltagelsen vokser på det private marked uden for deres regi. I den forstand er den brede, folkelige idræts lystlogik, hvor idrættens proces er vigtigere end resultatet, og hvor midler og mål karakteriseres som en kombination af »legen, kampen, dansen og fordybelsen« (Eichberg \& Bøje, 1997 p. 30), blevet kraftigt udfordret af motionskulturens intensive fokus på effektiv kalorieforbrænding og kropsmanipulerende træningsformer.

Samtidig er der konsensus i idrætsforskerkredse om, at sundheds- og kaloriepolitikkens status er blevet et centralt emne i idrætsforskningen og legitimeringsprocesser, både for den enkelte udøver og i forskningens genstandsfelter. Idræt legitimeres på alle niveauer både via selvvurderede og objektive sundhedseffekter, hvilket i stor stil har suppleret tidligere henvisningsrutiner, der påpegede civilsamfundets rolle som bibringer af social kapital, national stolthed og identitet $\mathrm{i}$ en demokratisk foreningskultur, som støbte samfundsbevidste borgere. I danske sociologiske idrætskredse hersker der generelt kritiske vurderinger af sundhedens indtog i idrætskulturen og den kommercielle fitness-sektors eksistens (Thing, L. F. \& Ottesen, L.). Men netop disse kritiske forbehold over for andre legitimeringsprocesser af idrætten kan samtidig være den medvirkende årsag til, at man endnu ikke har formået at føre mere håndfaste beviser for idrættens klassiske værdier på en overbevisende måde. Idrættens bløde kulturelle værdier genfortælles og omtales ofte, men effektmålinger og dokumentation holdes endnu på afstand i misforståede forsøg på ikke at værdisætte og indeksmåle idrættens kerneværdier. Uden at komme svarene nærmere spørger man sig selv om, 'hvordan man skal føre bevis for dis- se værdier - og om bevisførelse overhovedet er en opgave for humanister eller samfundsvidenskaben'. Via de manglende besvarelser undgås en instrumentalisering af idrætten, lyder argumentet, mens man affinder sig med, at man i idrætspolitiske debatter og diskussionen om 'idrættens værdier' står svagt på grund af den manglende kvantitative empiri. Den manglende interesse for dokumentation overlader legitimeringsopgaven til sundhedslogikkens hårde empiri, som synes vanskelig at argumentere imod, når sundhedsfacts om f.eks. fodboldens sundhedsfremmende virkninger smækkes på bordet med klar fokus på boldspillets positive sundhedseffekt: "De nærværende undersøgelser har vist at fodboldtræning i to-tre timer om ugen giver markante forbedringer $\mathrm{i}$ fysisk form og sundhedsprofil som følge af både kardiovaskulære, metabolske og muskulo-skeletale tilpasninger, uafhængig af køn, alder og manglende erfaring med fodbold. Det er yderst positivt, idet en lystbetonet holdidræt ... kan bidrage til fastholdelsen af en fysisk aktiv livsstil« (Krustrup, 2010). Overgangen fra den fine, romantiske indpakning af idrættens bløde værdier bliver hermed blotlagt af idrættens nytte.

I idrætspolitiske debatter er de kritiske røster direkte medvirkende til, at idrættens kvalitative værdier er trådt i baggrunden, mens fokus er blevet flyttet til idrættens nytteværdi og på det konkrete og målelige 'outcome', hvor idræt bliver til midlet, der kan fremme folkesundheden, redde de inaktive og overvægtige og formindske sygefraværet for landets arbejdsgivere. Politiske beslutningstagere tøver ikke med at spænde idrætten for en sundhedsvogn, som idrætten måske ikke kan, bør eller ønsker at trække.

For fitnesskunder spiller sundhed logisk en stor rolle. Argumentationen er, at man via træningen her er ganske sikker på at få sundhed for 


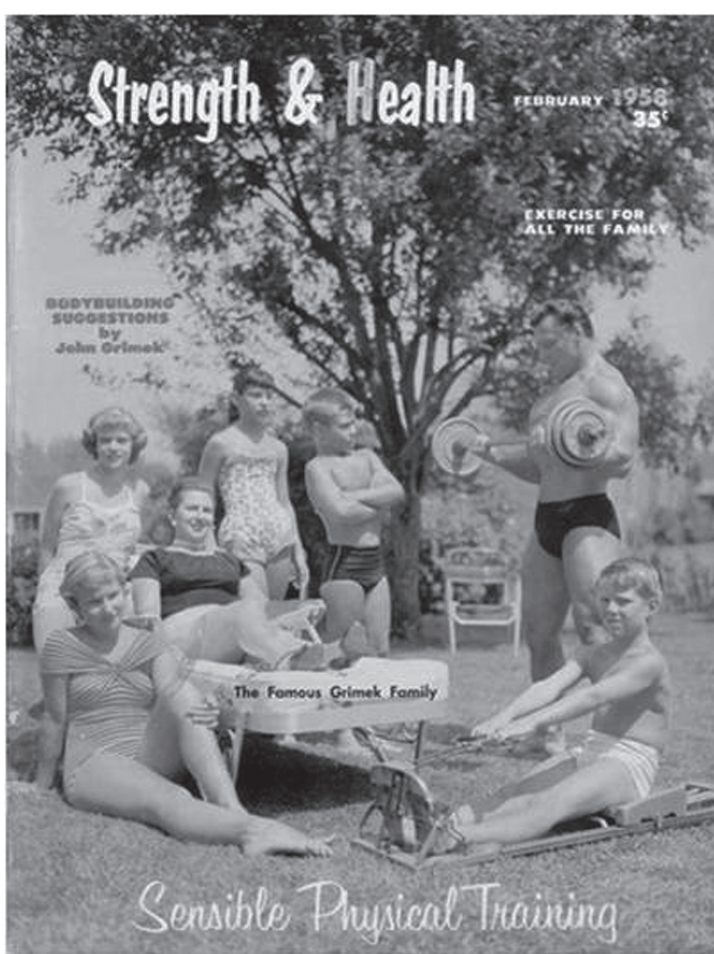

Den amerikanske familiefar viser vejen til det lykkelige liv. Via hård træning får du stæerk krop og karakterstyrke - og efter kommer den smukke kone nok også. Sønnerne efterligner deres far, mens døtrene ser passivt på. Kønsrollernes stereotype kontraster står klart på forsiden af magasinet Strength and Health fra 1958.

pengene. "Value for Money« argumentet forudsætter en rationel tilgang til idrættens praksisformer og kalder derved på dokumentation frem for henvisning til kulturel habitus. Satsningen på sundhed som fitnesscentres primære produkt har medvirket til en enorm vækst af kommercielle fitnesscentre. For landets 453 privatejede fitnesscentre med ca. 550.000 fitnesskunder (Kirkegaard, 2010) er selve udgangspunktet en brutal instrumentalisering af idrættens værdier.
Hvis idrætten ikke på den ene eller anden måde kan bevises, så har den ingen værdi for kunden! Dette viser nye empiriske studier af aktive fitnesskunder, hvor hovedparten af fitnessaktive oplever markante helbredsmæssige fremskridt som følge af fitnesstræning. Den kommercielle fitnessbranche bidrager med stor sandsynlighed positivt til såvel den enkelte aktive fitnessudøvers som samfundets generelle sundhedstilstand (Kirkegaard, 2009 p. 25-39). Men branchen udklækker også idrætsaktive, der i højere grad spørger kritisk ind til, hvilken kvalitet og hvilket serviceniveau man kan forvente for prisen.

Når ovenstående rationelle vurdering af idræt træder markant frem, finder idrættens legitimeringsproces også andre veje end det kvalitative fokus på de klassiske værdier. Den samtidige underliggende 'får-vi-nok-for-pengene-logik' genfindes inden for store dele af kulturpolitikken, hvor den trækker et spor af konkrete politiske initiativer og evalueringer efter sig. Den sætter idrættens hovedorganisationer, DIF, DGI og Firmaidrætten under pres, fordi henvisningen til idrættens traditionelle værdier kun i begrænset omfang kan hamle op med de hårde empiriske beviser på idrættens sundhedsfremmende betydninger. Især Danske Gymnastik- og Idrætsforeninger samt Firmaidrætten forsøger i høj grad at udforme idrætsaktiviteter i forhold til det nye sundhedskodeks. Der udvikles sundhedscertificeringer til arbejdspladser, og der skabes nye idrætsaktiviteter til tidligere fysisk inaktive målgrupper. Idræt benyttes i højere grad som midlet i jagten på idrætsuvante målgrupper, og sundheds- og nyttemotivet kan genfindes i den politiske omtale af både nye og gamle aktiviteter i foreningsidrætten. Traditionen med, at idrætten er organiseret for dem, der har en interesse og kommer af sig selv, er nu via rækken nye sundhedsorienterede aktivitetstil- 
tag blevet suppleret med en interesse for de fysiske inaktive. Derved bevæger dele af foreningsidrætten sig væk fra en årelang tradition, hvor legitimering af idrættens praksisformer blev holdt oppe af den frivillige deltagelse, som ikke forudsætter segmentering og målrettede motionskoncepter.

\section{PLIGTEN TIL LYST - ELLER "TRANG" SOM SYNTESE?}

Idrættens to modstridende motiver med lyst og pligt kan illustreres via nedenstående model (se figur 5), som primært skal læses som forsøget på en nuancering af lyst-pligtskalaen, og hvor især pilenes funktion illustrerer et forsøg på at løse op for dualismen mellem lyst og pligt, som er repræsenteret ved henholdsvis venstre side af $\mathrm{x}$ aksen og højre side af $\mathrm{x}$-aksen.
Y-aksen skelner mellem holdbaserede og individuelle idrætsformer, hvorved modellen via pilen samtidig er en beskrivelse af, i hvilken retning idrættens to modstillede logikker og traditioner bevæger sig. Via pilene illustreres de respektive idrætslogikkers oprindelse og udvikling. Sportens lege, der kun finder mening og legitimeres af sin egen eksistens, står som modstridende idrætslogik.

Modellens empiriske postulat er, at de to yderpunkter med lystens og pligtens modsættende logikker nærmer sig hinanden i idrættens udvikling, hvilket illustreres med pilenes retning. Dette sker både i udviklingen af konkrete idrætsaktiviteter, i de aktives motiver og begrundelser for idrætsdeltagelsen samt i selve den idrætspolitiske legitimering af idrætten. Den kommercialise-

Figur 5. Idrættens udvikling, organisering og udvikling

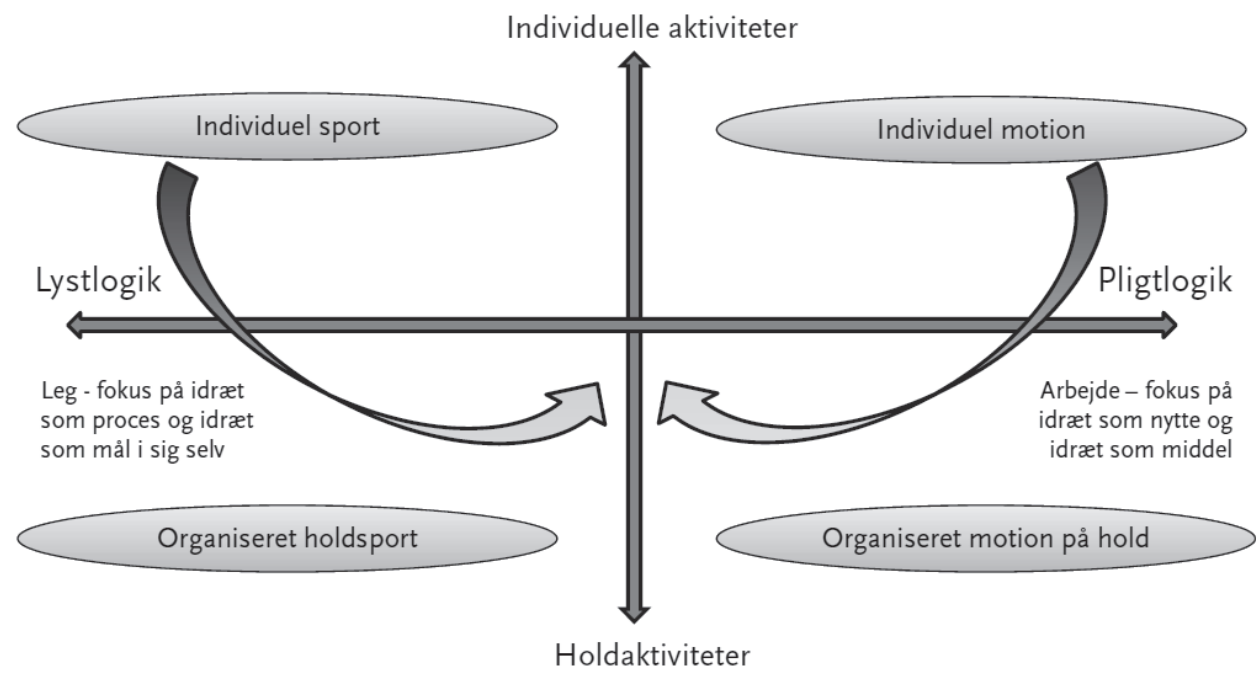


rede motionskultur kan ikke længere leve alene ved at udbyde en fleksibel og uforpligtende individuel motionstræning, hvor gennemstrømningen af kunder medfører ustabile indtægtskilder. Pilen fra krydsningen mellem den individuelle idræt og arbejdslogikken (øverste højre hjørne) illustrerer således en udvikling inden for motionskulturen, hvor basale styrke- og konditionstræningsøvelser i deres udspring var individuelle og mandsdominerede aktiviteter (bodybuilding), som samtidig var selve forudsætningen for motionskulturens kommercialisering, da de ikke forudsatte omkostningskrævende organisering og planlægning af tid og sted, men i starten blot krævede træningsfacilitetens rum og træningsredskaber (Kirkegaard, 2007). Ved fitnesscentres intensive fokus på individet og mødetidens ophævelse blev den fleksible idrætsorganisering introduceret til stor glæde for især kvinder, der ikke tidligere havde samme mulighed for at være idrætsaktive på grund af oplevet alment tidspres (Kirkegaard, 2009 p. 52-59). Pilen illustrerer via dens forløb fitnessbranchens introduktion af holdbaserede og gymnastikinspirerede koncepter (aerobic og spinning), som tilføjede et afgørende element af socialitet til motionskulturen. Denne udvikling er blevet udbygget med talrige andre sociale aktivitetsformer, herunder klassiske holdaktiviteter (f.eks. fodbold, cykling, gymnastik, zumba), som foreningsidrætten tidligere sad tungt på. På den måde har motionsaktiviteterne og fitnesscentre medvirket til at udvikle en kropskultur, der trods sit udspring i pligtlogikken nu også i dag spiller på lyst, (sammen)spil og dansens mere lystfyldte processer. Den venstrestillede pil illustrerer den lystbaserede og ofte foreningsorganiserede idræts problemer, hvor væksten i idrætsdeltagelsen finder sted uden for den klassiske organiserede idræt, hvorfor der udvikles strategier for foreningskulturens møde med den fleksible motionskulturs implicitte pligtlogik og sundhedsfokus. Sundhedscertificering, foreningsfitness og motionsprojekter som 'Start to Run' er oplagte eksempler herpå.

I det empiriske perspektiv forvandles træningens sure pligt dog hurtigt til en mere knudret og sammensat størrelse; især når den organiseres og praktiseres som holdaktiviteter i socialt selskab med andre. Samtidig vil fitnesskulturens udvikling afsløre, at træningsformerne med fokus på effekt og også repræsenterer en samtidig lyst. For det er lige præcis, når det gør allermest ondt, at man er tættest på forløsningen og lystfølelsen; nemlig følelsen af at kunne tæmme sin egen krop og overvinde sig selv: "Hvor meget smerten kommer til at ryste én, afhænger af ... ens forventning om at have kontrol. Idræt er kendetegnet ved ønsket om at opnå kontrol« (Roessler, 2002 p. 98). Idrættens grænser handler således om at beherske teknikker og egne færdigheder og søge sine grænser ved momentvist at opleve kontroltab, som opstår ved manglende evne eller erfaring ved den fysiske smerte. Det fysisk hårde motionsarbejde fortolkes på baggrund af ens "... kultur, biografi, oplevelser og mestringsadfærd « (Ibid. p. 97), og den fysiske smerte er dermed glædens følgesvend og omvendt. Den aktives evne til at skelne mellem god og dårlig smerte er udtryk for motionistens praktiske erfaringer, der forfiner fornemmelsen af at kende forskelle mellem en følelse af ømme muskler og en overbelastningsskade (Hedblom, 2009). Det gør ondt at vinde og smerte er prisen for at vinde over sig selv.

Samtidig kunne det være interessant at undersøge, hvordan andre aktiviteters idrætsdeltagere ville svare på konstruerede modsætninger mellem lyst og pligt. En sandsynlig tese vil være, at man i hovedparten af de traditionelle holdba- 


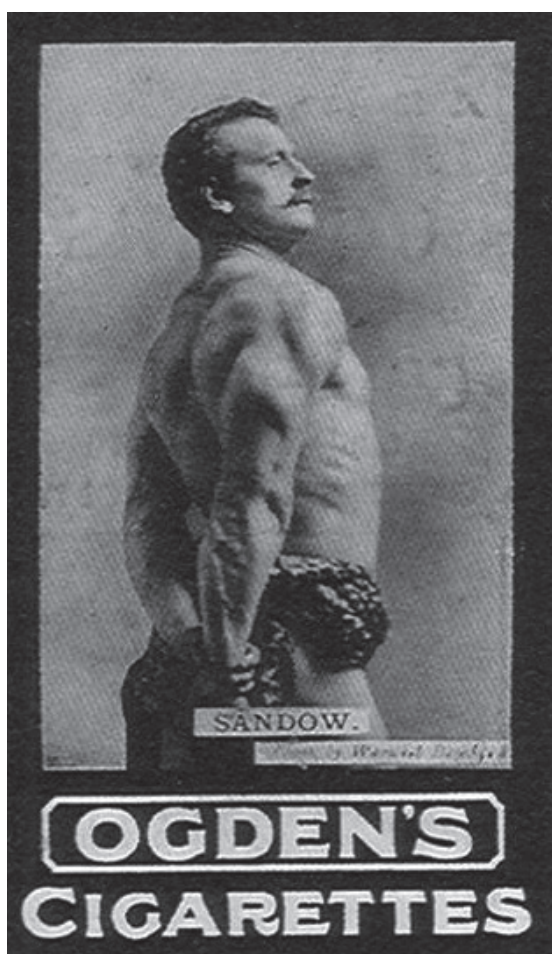

Eugen Sandow 'The Magnificient' var verdens første professionelle bodybuilder. Dengang kunne man godt være sund og stadig nyde en cigaret. Reklame fra starten af år 1900.

serede idrætsaktiviteter $\mathrm{i}$ foreningsregi finder idrætsaktiviteter, som i højere grad er kendetegnet ved lyst, og hvor endnu flere ville være enig i udsagnet om, at 'den er motiverende i sig selv'. Hvis det er tilfældet, kan den principielle skelnen mellem de pligt- og lystbaserede idrætskulturer opretholdes. Samtidig kan fitnesskulturens funktionelle idrætstilgang nu italesættes i mere nuancerede, anerkendende og empirisk underbyggede udsagn, hvor træningen for den enkelte udøver sagtens på én gang kan indeholde lystprægede aktiviteter, som i udspringet el- lers byggede på nytteorienteret pligtlogik, hvor træningen blev legitimeret som effektiv og kom til udtryk via ønsket om konkrete målelige resultater (mere sundhed, bedre udseende, mindre kropsvægt).

Når følelsen af lyst og pligt smelter sammen og finder sted på samme tid i samme aktivitet, kan deres principielle modsætninger ikke længere opretholdes. De kan oversættes til en følelse af en trang, der både kan italesættes og praktiseres som en udefrakommende »struktur «-med udsagn som "trænger du ikke til at få rørt dig» - og som et internt anliggende som en drift »jeg trænger til at få mig rørt«. Trangens begreb rummer derfor både omverdenens sociale og kulturelle rammesættende betingelser samtidig med, at den har klare psykologiske og fysiologiske berøringsflader. Trang er med andre ord et begreb, der både bærer lyst og pligt i sig. Begrebet rækker ind i både socialpsykologiske og samfundsmæssige normbaserede konstruktioner. Individet påvirkes og påvirker på én gang selv kulturens retningsfornemmelse af 'oplevet nødvendighed' - f.eks. en stærk følelse af trangen til at udføre 'den nødvendige træning' for at holde kroppen ved lige.

Forskellen på de nytte- og legeorienterede idrætter skal således italesættes med respekt for, at de fleste aktive selv kan forholde sig nuanceret til deres kropslige erfaringer og oplevelser, hvor der er rig mulighed for at kombinere en pligtdrevet motivation med oplevelsen af glæde over selve aktiviteten. Det er derfor naivt at betragte fitnesskundernes besvarelser som udtryk for en fri og utæmmet lyst, som er fri for kulturelle normer og samfundsforherligede værdier. Der kan sagtens være tale om, at pligten udtrykkes som lyst - og omvendt. I foreningsidrættens frivilligt organiserede og lystprægede idrætskultur taler man således om 'det forplig- 
tende fællesskab'. Den enkelte respondents fortolkning af idrætsaktiviteten er uden tvivl underlagt stærk kulturel indflydelse, fordi valget af pligtbetonede idrætsformer kan medføre social anerkendelse. Argumenter for, at vi lever i en 'viagra-kultur' (Rösing, 2010 p. 12), hvor alle har pligt til lyst uanset tid og sted, står centralt i denne fremstilling. Det moderne menneske er så at sige præget af en forestilling om, at vi gør, og skal gøre, ting af lyst og fri vilje. Pligt opfattes ganske enkelt som et negativt begreb og som noget påtvunget, ufrit, som bliver os pålagt. På den anden side vil en overdrivelse og overfortolkning i den kulturkritiske fremstilling grænse op til begrebet 'falsk bevidsthed', som hævder, at individer kan reproducere 'forkert' systematisering af erfaringer og derved give udtryk for en falsk lyst og en forkert opfattelse og ureflekteret tilfredshed med tingenes tilstand. En sådan udlægning medfører ufravigeligt en formynderisk tilgang til andres erfaringer.

Men begrebet 'trang' tager i modsætning til 'den falske bevidsthed' udgangspunkt i individets konkrete erfaringsdannelse: Man kan ikke forestille sig længsel efter noget, som man ikke har konkrete kropslige, psykologiske, sociale eller mentale erfaringer med (Ulseth, 2007 p.28). Trang kan således være pligten og lystens syntese - smeltet sammen i et nyt begrebsligt Janus-ansigt - tragedie og komedie på samme tid. Livet med trang kan karakteriseres som et liv med oplevelser, hvor lidelse, afsavn og nydelse kommer til udtryk som krydderier på dagligdagen og potentielt kan resultere i momentvise fornemmelser af frihed, der opnås via en disciplineret lyst og en begrænset pligt. Friheden indfinder sig dér, hvor man selv er i stand til at sige til og fra, og hvor der ikke længere er nogen kamp mellem pligt og lyst.

\section{LITTERATURLISTE}

Baudrillard, J. (1987). Amerika. (1. udgave.) Akademisk Forlag.

Bøje, C. (1989). Kultur, krop og sundhed - sociale og politiske betragtninger. Månedsskrift for praktisk lagegerning.Tidsskrift for praktiserende laegers efteruddannelse.Udklipssartryk, 939-952.

Bøje, C. (1997). En velfungerende ryg - et biprodukt af lyst. Månedsskrift for praktisk loegegerning.Tidsskrift for praktiserende lagers efteruddannelse., 75. årgang.

Dekkers, M. (2008). Kropskultur. (1. udgave ed.) Århus: Tiderne Skifter.

Eichberg, H. \& Bøje, C. (1997). Idrcetspsykologien mellem krop og kultur. 2. oplag. Idrætsforsk og DGI.

Ferry, B. (1985). Boys and Girls. Slave to Love. EG Records.

Kirkegaard, K. L. (2010). Fitnessbranchen trodser krisen. www.idan.dk Retrieved, 12-22010 from http://www.idan.dk/Home/ Kommentaren/056fitnessaaret.aspx

Kirkegaard, K. L. (2009). Portraet af de aktive fitnesskunder - trceningsmotiver, tilfredshed og selvvurderet sundhed. Delrapport 2 i projektet 'Sundhed for millioner'. (Rep. No. 2). København: Idrættens Analyseinstitut.

Kirkegaard, K. L. (2007). Fra muskelmasse til massebevagelse - indblik $i$ den kommercielle 
fitness-sektors historie. København: Idrættens Analyseinstitut.

Krustrup, P. (2010). 50 forskere: Fodbold forbedrer sundhed, fitness og social interaktion. Pressemeddelelse af 9. april 2010. Retrieved, 9-4-2010 from: http://www.ifi.ku.dk/Forskning/projekter/ integreret_fysiologi/pk_projekter/pressemeddelelse_9_april/

Møller, J. (2001). "Nærvær« - forsøg på en nem definition af leg. Idrcetshistorisk Årbog 2001, 141-154.

Pilgaard, M. (2009). Sport og motion i danskernes hverdag. (1. udgave ed.) København: Buchs.

Roessler, K. K. (2002). Når idraet gør ondt - skader, smerte, stress. Århus: Forlaget Klim.

Rösing, L. M. (2007). Autoritetens genkomst. København: Tiderne skifter.

Tennant, N. (1987). Actually. It's a Sin. Pet Shop Boys. Parlophone.

Thing, L. F. (2010). Idrætssociologiske fremtidsscenarier: Idræt, politik og velfærd. In Poulsen m.fl.(red.). (Ed.), Et nyt forskningsfelt $i$ et nyt 100-årigt perspektiv. (pp. 309-312). København: Museum Tusculanums Forlag og Institut for Idræt, Københavns Universitet.

Thing, L. F. \& Ottesen, L. 2008: MacDonaldisering af den danske idrætskultur, i: Idrcetshistorisk Årbog. København: Forum for Idræt, Historie og Samfund.
Ulseth, Anne-Lene Bakken. 2007: Mellom tradisjon og nydannelse. Analyser av fysisk aktivitet blant voksne $i$ Norge. Oslo: Institutt for sosiologi.

\section{NOTER}

1. Citatet "Gør din pligt og kraev din ret" stammer fra in skriptionen på de første danske socialistiske og socialdemokratiske faner, som var med i slaget på Fælleden i 1872.

2. Studiet er baseret på 77 kommercielle fitnesscentre. Et tæt samarbejde med de deltagende fitnesskæder og centre resulterede $\mathrm{i}$ en tilfredsstillende svarprocent på 54,8 og i 4.747 besvarelser. For nærmere metodebeskrivelse og andre empiriske fund, se: Kirkegaard, 2009.

3. Der er statistiske signifikante sammenhænge mellem alder og træningsmotiver.

4. Der er tale om statistisk signifikante sammenhænge. 